The role of civil society in reducing poverty and inequality: A case study of the living wage campaign in the UK

\section{Paul Bunyan}

Edge Hill University, UK
2016, Vol. 3I (4) 489-50।

(C) The Author(s) 2016

Reprints and permissions: sagepub.co.uk/journalsPermissions.nav

DOI: I0.I I77/02690942I6646993

lec.sagepub.com

\begin{abstract}
The introduction of the national minimum wage at the end of the 1990s in the UK represented an important intervention by the then New Labour government but it has remained too low to effectively address increasing levels of in-work poverty and inequality. This article traces the development of the living wage campaign, initiated and led by Citizens UK and its main affiliate London Citizens from 200I onwards and what it has to say about the role and potential of civil society in addressing issues of poverty and inequality.
\end{abstract}

\title{
Keywords
}

civil society, community organising, inequality, living wage, London citizens, poverty

\section{Introduction}

The announcement of a 'national living wage' by the Chancellor of the Exchequer, George Osborne in the summer 2015 budget moved the idea of the living wage to the centre of national politics and media attention in the UK. The policy generated much public debate seen by some as a radical step to address low pay and in-work poverty, by others as a welcome hike in the minimum wage but significantly short of a living wage and by others still, as an audacious attempt to co-opt the living wage 'brand' as cover for welfare cuts targeted at the poor.
This article traces the development of the living wage campaign, initiated and led by Citizens UK and its main affiliate London Citizens from 2001 onwards.

In the first part of the article two conceptual frameworks are utilised to explore broader questions about the role and potential of civil society in addressing issues of poverty and inequality and promoting social justice - first, Edwards three-fold

\section{Corresponding author:}

Paul Bunyan, Department of Social Sciences, Edge Hill University, Ormskirk, L39 4QP Lancashire, UK.

Email: paul.bunyan@edgehill.ac.uk 
model of civil society, understood as associational life, the good society and the public sphere; second, the distinction between redistribution and recognition which has informed recent philosophical debates, most notably between Nancy Fraser and Axel Honneth, about the nature of social justice. In the second part of the article key features of the living wage campaign in the UK and the community organising approach which has been central to its success are explored, including its origins, tactics employed, milestones achieved and, in light of the 'national living wage', potential future direction. In the final part, the living wage campaign and the organising approach upon which it is based are evaluated against the conceptual framework established and broader questions about the possibilities for radical forms of democratic politics located in civil society are explored. The article concludes that the living wage campaign and the approach of community organising more generally represent one of the most important civil society-led initiatives to reduce poverty and inequality in the UK in recent decades.

\section{Conceptualising civil society approaches to addressing poverty}

\section{Edwards' three-fold model of civil society}

According to Michael Edwards (2010), a leading writer and authority on the subject, civil society is best understood as encompassing three interrelated dimensions civil society as the world of associational life, civil society as the good society and civil society as the public sphere.

Civil society as associational life is the orthodox and most common understanding of civil society. Here, civil society is understood as the myriad of groups and intermediary institutions which stand between the individual/family and the state.
In addressing poverty, civil society understood as associational life encompasses the many ways in which individuals, groups and local institutions respond directly to need. Among other things, they include, individual acts of kindness, generosity and charitable giving, the work of volunteers in charities and third sector organisations providing support and advice on welfare, advice and debt, and the work of faith groups such as the Salvation Army, the Catholic Society of St Vincent de Paul (SVP) and Muslim Aid who provide assistance to the poor and disadvantaged. Whilst many of these works and acts of charity might represent short term alleviations rather than longer term solutions to reducing poverty, they nevertheless represent an important part of the picture of how people individually and collectively in their localities and institutions respond directly to poverty and seek to make a difference to the world around them.

Civil society understood as the good society encompasses the realm of ideas and competing narratives about the nature of a good society and how it might be achieved. Issues of poverty and inequality lie at the heart of debate about what a good society looks like and civil society organisations contribute to and inform such debate in a number of ways. For example charitable trusts and Foundations, such as the Joseph Rowntree Foundation and the Webb Memorial Trust provide an important source of ideas, analysis and funding aimed at establishing a fairer and more just society. Faith groups too, often provide strong countercultural narratives which challenge stereotypes of people in poverty and promote social justice. Church Action on Poverty, for example, produced a report, entitled 'The Blame Game Must Stop' (McCarron and Purcell, 2013) challenging the stigmatisation of people living in poverty.

Civil society understood as the public sphere encompasses the political realm and ways in which civil society organisations 
seek to build sufficient power and legitimacy to shape public policy and contest the public sphere. The activity of unions and social movements provide examples of civil society organisations which adopt an overtly political approach in seeking to bring about change. In recent decades, shaped by neoliberal ideology, social and political change has tended to be framed as more consensus-based, i.e. in terms of increased co-operation between the state, market and civil society. For example, 'partnership' under New Labour and the 'Big Society' under the Conservative-led coalition both countenanced an ever greater role for civil society and more equitable relations between the different sectors state, market and civil society. In reality the opposite has largely been the case as neo-liberal hegemony, actively promulgated through what Harvey (2005) has referred to as the 'state-market nexus' has remained firmly entrenched. Through the employment of 'managerial technologies' (MacKinnon, 2000) and private sector practices, such as contracting and commissioning, the practices of civil society and third sector organisations have been impacted significantly, involving, among other things, a shift towards service delivery at the expense of other forms of engagement such as advocacy and campaigning (DeFilippis et al., 2010).

For the purpose of analysis Edwards' three dimensions have been separated out but it is in understanding the ways in which they are inextricably linked that deficiencies in the response of civil society to poverty and inequality can be best conceptualised. As Edwards says, 'Standing alone, associational life, the public sphere and the good society are each incomplete. Side by side, there is at least a chance that their strengths and weaknesses can be harmonised, and that all three can benefit from a positive and conscious interaction' (2010: 106). To this end, the capacity for civil society to effectively address poverty and inequality can be understood as being weakened to the extent that the dimensions are seen in isolation from each other. For example, an approach which focuses on individual agency and charitable giving, but pays little attention to the structural nature of poverty and the need for engagement in the political and public sphere will not lead to sustainable and long-term solutions. Similarly, a coherent and rational argument about how best to tackle poverty, or a vision of the good society divorced from a political strategy or local institutional support, will lack roots and legitimacy and fail to materialise. Put in more positive terms poverty is most effectively addressed by civil society when strategies are employed which encompass all of the dimensions of civil society identified by Edwards. Later in the article, I shall argue that the living wage campaign in the way it has developed in the UK provides a good example of a civil society initiative which in encompassing each of the dimensions identified by Edwards has developed the political efficacy to bring about significant change.

\section{Social justice as redistribution and recognition}

Issues of poverty and inequality lie at the heart of the struggle for social justice and a fairer society. In recent philosophical exchanges and debates claims for social justice have increasingly been divided into two types. On the one hand, social justice is understood primarily in redistributive terms, as a more just distribution of resources and wealth from, for example, the North to the South, from rich to poor and from owners to workers (Fraser and Honneth, 2004). On the other hand, the struggle for recognition by groups and peoples who suffer injustice has gained increasing currency as the best way for social 
justice to be understood and conceptualised. To quote Axel Honneth, one of the main protagonists of such a view '... what is needed is a basic conceptual shift to the normative premises of a theory of recognition that locates the core of all experiences of injustices in the withdrawal of social recognition, in the phenomena of humiliation and disrespect' (Fraser and Honneth, 2004: 134). In thinking about the role of civil society in addressing issues of poverty and inequality the distinction is helpful both in terms of understanding the ways in which social justice claims based on redistribution have been weakened over time and in understanding tensions which exist particularly between those on the Left, who place the emphasis on either redistribution or recognition, a combination of both or indeed other concepts in advocating different approaches to social justice.

In terms of understanding the weakening of social justice claims based on redistribution it is important to understand changes in the political economy from the Second World War onwards. In very broad terms, the social democratic consensus from the end of the Second World War to the 1970s saw the state play a central role in regulating the market and in building the welfare state, leading to significant advances in addressing levels of poverty and inequality in the UK. In the early 1970s in an increasingly turbulent economic climate, the postwar social democratic consensus began to break down, prompting fundamental assumptions about the role of the state in the provision of social welfare to be questioned (Fraser, 2003). The turn to the market heralding the era of neoliberalism from the 1980s to the present day has seen a steady rise in inequality and fluctuating but significantly high levels of poverty. One of the effects of neoliberalism and its predominance from the 1980s onwards has been to weaken social justice claims based on redistribution. The erosion of the power of unions combined with austerity in recent years has further weakened such claims. This has been problematic for those on the Left who continue to see the state as the primary means for creating a more equal and just society. It has also been problematic for civil society which has depended upon the state for resources and to intervene to protect citizens from the exploitative excesses of the market.

In recent years the term 'pre-distribution', has increasingly been used to signal a shift away from the state as the primary arbiter of the means of redistribution. Predistribution refers to the processes by which the market distributes its rewards before government gets involved, through for example the work of unions and wages councils. In September 2012, in a speech in the City of London Ed Milliband unveiled his 'pre-distribution' plan saying that instead of redistributing wealth through the tax and benefit system, there should be more 'pre-distribution', based upon a higher skilled, higher waged economy, rather than the 'top-up' of wages through redistribution. How this was to translate into policy remained largely moot, given sensitivities at the time around Labour's pro-business credentials. Milliband's successor Jeremy Corbyn has been more specific, recently proposing barring companies from distributing dividends unless they pay the living wage. Whatever the policy implications the substantive point is that within the context of neoliberalism and '.. at a time when there is little enthusiasm, for both ideological and practical reasons, for increasing the role of the state' (Wills and Linneker, 2014: 183) claims of social justice through state intervention on a redistributive or predistributive basis has become increasingly hard to make particularly in the arena of electoral politics.

Alongside, or in contradistinction to redistribution, increasing attention has been paid in recent years to the notion of 
recognition in theorising the nature of social justice. In 'Justice and the Politics of Difference', Iris Young challenges what she sees as the reduction of social justice to distributive justice. Young says,

In criticising distributively oriented theories I wish neither to reject distribution as unimportant nor to offer a new positive theory to replace the distributive theories. I wish rather to displace talk of justice that regards persons as primarily possessors and consumers of goods to a wider context that includes action, decisions about action, and provision of the means to develop and exercise capacities. (1990: 16)

In developing a conception of justice around recognition and the effects of domination and oppression rather than distribution, Young envisages social justice as arising from the expression of plurality, diversity and difference, as dominated and oppressed groups, including women, Black people, homosexuals and disabled people act in collective and democratic ways to challenge such injustices. Young's approach to social justice provides a strong conceptual framework for thinking about the role of civil society and social movements in addressing poverty and inequality and promoting social justice. Essentially, in the words of Young it is '... to promote a politics of inclusion ...' through which '... participatory democracy must promote the ideal of a heterogeneous public, in which persons stand forth with their differences acknowledged and respected, though perhaps not completely understood, by others' (p. 119). This understanding approximates closely with the approach of community organising upon which the living wage campaign has been based, features of which will be highlighted later in the article.

Nancy Fraser, another leading theorist of social justice, advocates a theory of social justice which combines both redistribution and recognition in a single normative framework. In an essay entitled 'Culture, Political Economy and Difference: On Iris Young's Justice and the Politics of Difference' (1997) Fraser takes issue with Young maintaining, among other things, that she overstates the recognition paradigm and that her treatment of political economy and the distributive paradigm is cursory and underdeveloped theoretically.

It is beyond the scope of this article to look in detail at the different theoretical arguments, often complex and competing, that have coalesced around the redistribution/recognition conceptual framework for understanding claims of social justice. But for the purpose of thinking about the role of civil society in addressing issues of poverty and inequality what some of these different theoretical perspectives point to is distinctions on the left between what can be described as state-centric as opposed to civil society-centric perspectives which place different emphases on the place of political economy, culture, structure and agency in explaining social and political change. This will be explored further later in the article in framing an understanding of the living wage campaign and the community organising approach as constituting a distinct form of civil society-led politics.

\section{The living wage campaign in the UK}

\section{Origins and early tactics}

The idea of a living wage has a long history going back to the nineteenth century. It was described then as the idea that 'wages should be sufficiently high to enable the labourer to live in a manner consistent with the dignity of a human being' (Bennett, 2012, quoting Ryan, 1906: vii). In more recent times the living wage is most closely associated with the campaign initiated in 2001 by London Citizens, 
the largest affiliate of Citizens UK, which for over two decades has promoted community organising as an approach to engaging citizens in political and social action.

The community organising approach has been central to the success of the Living Wage campaign in the UK. Community organising understands social change as being both a consensus and conflict based process with an analysis of power central to the strategy and political tactics employed. Power to engage in the political process and the public sphere is generated through the institutional membership of the organisation, made up of faith groups, schools, universities, charities, unions, community groups and housing associations. London Citizens now has over two hundred and fifty member organisations across the Greater London area. The organisation works on a multi-issue agenda which alongside the flagship living wage campaign also includes campaigns on social care, jobs, affordable housing, street safety, challenging usury, the resettlement of refugees and ending the detention of children in the UK asylum process.

The prevalence of in-work poverty has shifted significantly in recent decades. More people in-work than out of work now experience poverty in the UK, challenging the assumption that work is the best way out of poverty. Wills and Linneker (2014) point to a number of reasons for the increased role of low wages in the causes of poverty, including the political attack launched on institutions of pre-distribution, such as unions and wage councils, by the Thatcher governments after 1979 and a national minimum wage, which whilst having a positive overall impact since being introduced by New Labour in 1998, nevertheless being set at too low a rate to stem the rising tide of in-work poverty. It is worth making the distinction at this point between a statutory minimum wage and a voluntary living wage (the issue of the 'national living wage' introduced in April 2016 will be discussed later in the article). The former refers to a legally binding figure set by the Low Pay Commission, according to a judgement about what employers can afford - it currently stands at $£ 6.70$ per hour for over 21 s and $£ 5.30$ per hour for 18 to 20 year olds. The latter by contrast is calculated based on the public's perception of what is needed for a minimum acceptable standard of living for different family types; in other words '... a living wage is designed to reflect the local cost of living and the real cost of life' (Wills and Linneker, 2014: 183). It currently stands at $£ 8.25$ outside London and $£ 9.40$ in London.

The modern living wage campaign was initiated in 2001 by The East London Communities Organisation (TELCO), the first chapter of London Citizens. The campaign significantly raised the profile of community organising in the UK bringing into membership for the first time, local union branches and helping to build alliances with some of the major national unions, most notably UNITE. The initial focus was on contracted cleaners servicing the large finance institutions based at Canary Wharf, including HSBC and Barclays. Public bodies such as Hospital Trusts, which also contracted out their cleaning services to large multinational companies were also targeted.

The approach in the early years was more agitational than conciliatory, focusing on the plight of contract cleaners, some of whom had to work two or in some cases three jobs to make ends meet. Many of the cleaners were from faith groups and union branches within membership of London Citizens. Tactics included action at shareholder AGMs, public assemblies, and in the case of hospital trusts, lobbying board meetings with large numbers of people. In most cases such action followed rejection by the financial institution or 
public body of an initial request for a meeting to discuss the case for the living wage and the opportunity for low paid workers themselves to talk about their experiences and the impact poverty wages was having on them and their families. In the first instance, therefore tactics reflected the need for recognition both in terms of the legitimacy of the organisation and the issue of a living wage. As the membership and the power and profile of London Citizens has grown, the political repertoire of action has also increased to include various forms of direct action and public assemblies, allowing the organisation to employ both consensus and conflict based tactics for advantage at different points of the campaign.

In the first few years the living wage campaign gathered increasing momentum but it remained relatively marginal to mainstream politics and public and media attention. Some of the organisations initially targeted did agree to increase the pay of their contracted cleaners, most notably HSBC, at its world headquarters in Canary Wharf where pressure from the campaign resulted in an increase in pay from $£ 5.00$ to $£ 6.00$ an hour in 2003. Most significantly, in 2005 the Mayor of London, Ken Livingstone and the Greater London Authority (GLA) set up the Living Wage Unit in response to a Mayoral election pledge made to London Citizens and since then the unit has been responsible for calculating the London Living Wage each year. Livingstone's successor, Boris Johnson has been a vocal supporter and advocate of the living wage since he took office in May 2008.

\section{Trust for London and The Living Wage Foundation}

In 2009, Trust for London, a charitable organisation which exists to reduce poverty and inequality in London, launched a special initiative aimed at significantly raising the profile and impact of the living wage. Between 2009 and 2013 the Trust invested almost $£ 1$ million in the campaign, which involved three main strands. First, increasing awareness raising and campaign work by London Citizens, with a focus on key sectors such as retail/hospitality, public (particularly local authorities) and higher education. Second, the creation of the Living Wage Foundation to accredit employers and to monitor on-going compliance, and third, ongoing research about different aspects of the living wage including assessing the costs and benefits to employers and workers of being paid a living wage.

An independent evaluation of the living wage initiative, carried out by Cambridge Policy Consultants, published in September 2014, indicated that the Trust had successfully delivered on what it set out to achieve. The report highlighted the establishment of the Living Wage Foundation as being a vital element in providing the infrastructure to support the 'mainstreaming' of the living wage and for putting in place a process to formally accredit living wage employers. Commenting on the continued role for community organising in the living wage campaign in future the report said:

The theory of change supporting the
Special Initiative and Citizens UK's
living wage work has shifted over the
course of the four-year initiative from a
campaigning model focused on reputa-
tional risk to one emphasising reputational
benefits. This has been successful because
the campaign was able to secure a main-
stream profile. (Cambridge Policy
Consultants, 2014: 9)

The balance between an emphasis on reputational risk and reputational benefit remains central to the campaign and the tactics employed. In crude terms, the 'carrot' of reputational benefit through accreditation, augmented on occasions by the 'stick' of campaigning by Citizens UK, 
including targeting and 'naming and shaming' organisations such as Tesco, Marks \& Spencers and Next, which fail to pay the living wage, continues to serve as an effective campaign strategy. The strategy also highlights both the significant role independent Trusts and Foundations can play in supporting civil society organisations to address issues of poverty and inequality and the importance of an independent broad-based community organisation able to deploy different tactics through having a large number of diverse institutions at a local level ready to turn out large numbers of people to take action.

\section{A 'national living wage'?}

The announcement in the 2015 budget of a 'national living wage' by the Chancellor of the Exchequer, George Osborne was unexpected and came as a surprise to many, not least the organisers and leaders within Citizens UK who had driven the campaign for many years. On one level it represented national recognition and a significant victory for Citizens UK after almost fifteen years of campaigning. However, at another level, it raised more questions than answers. As one commentator remarked about the 'national living wage' - 'Just because I call my cat Rover, it doesn't make it a dog' (Kelly, 2015). Initial analysis of the implications of the National Living Wage (NLW) by the Resolution Foundation referred to a 'terminological muddle'. The report said:

The title of the new policy - the National Living Wage (NLW) - adds significant confusion to what was already a muddled debate on the purpose and definitions of the various rates. The NLW is a large increase in the legal wage floor, a role that is currently played by the National Minimum Wage (NMW). The Living Wage as we know it is overseen by the Living Wage Foundation and has a very different logic underlying it. The Living
Wage is calculated based on the public's perception of what is needed for a minimum acceptable standard of living for different family types. It is a voluntary wage rate that employers are encouraged to pay to help workers and families achieve that standard. (D'Arcy and Kelly, 2015: 3)

This wasn't the first time that a Conservative-led government had co-opted ideas and practices from Citizens UK for political ends. At the beginning of the last parliament in 2010 the coalition government launched the community organiser programme to train 5000 community organisers as part of the 'Big Society' initiative. Having successfully pioneered community organising in the UK and with a strong track record, Citizens $\mathrm{UK}$ had been the frontrunner, to run the multi-million pound government contract but lost out in the end to the organisation 'Locality'. In the case of the community organising programme the government-sponsored version differed markedly from the practices and philosophy of Citizens UK and the same can be said now of the 'national living wage'. Should this really matter? In translating the ideas and practices of civil society into policy did it not represent recognition on the part of government for the work and achievement of Citizens UK over many years? Yes, but only up to a point - the problem being that in both cases government co-option of civil society practices and initiatives, changed fundamentally their original orientation and intention.

It is difficult to project the future direction of the living wage campaign, given the introduction of the national living wage in April 2016. Interestingly, but perhaps not surprising given the more limited impact the national living wage will have on Londoners (and putting aside his mediahyped rivalry with George Osborne for the future Conservative party leadership), Boris Johnson has made a number of utterances about the importance of keeping in focus 
the living wage as accredited by the Living Wage Foundation and in his words "not letting the wind go out of the sails of the campaign'. The recent decision by IKEA and ALDI, after the announcement of the national living wage, to become the first major retailers to agree to pay the accredited living wage, represents a significant breakthrough for the campaign and may well signal its future direction as companies consider the reputational benefits and choose to trump the national living wage and align themselves with a progressive cause and campaign. Over two thousand companies and organisations are now accredited living wage employers. The institution in 2013 of a living wage week each year in the first week of November during which the new rates for London and outside London are announced has also provided an important focal point keeping the issue of in-work poverty firmly on the political agenda. That said, the introduction of the national living wage in April 2016 has the potential both for confusion and for diluting the salience of the accredited living wage. In response to this the Living Wage Foundation announced at the beginning of January 2016 that a new eight-member commission was to be set up, chaired by Gavin Kelly, Chief Executive of the Resolution Trust and also including Frances O'Grady, General Secretary of the TUC, to spearhead efforts to win over more employers to the higher accredited living wage.

\section{The role of civil society in promoting social justice}

The living wage campaign has been sustained over many years. In this final section, with reference to the earlier discussion on the conceptualisation of civil society and social justice, I shall draw out some of the ways in which this has been achieved, highlighting in particular the significance of the broad based community organising approach upon which the campaign has been built.

First, in terms of civil society as associational life, the institutional membership of London Citizens, now numbering over two hundred and fifty organisations, has driven the campaign connecting to low paid workers within a diverse range of organisations and localities and providing the support, people and leadership that has sustained the campaign over many years. In terms of social justice understood as recognition, the building of power through collective action for recognition within the context of the public sphere, represents the fundamental purpose and raison d'etre of community organising. Recognition is understood in terms of struggle, dignity and respect, exemplified in the involvement and personal testimony of low paid workers at public actions and large public assemblies which has been central to the strategy and tactics employed in the campaign. The community organiser, Michael Gecan, in his book 'Going Public' highlights the significance of power and recognition as the driving force of change in the world as it is. He says:

Without power there is no real recognition. They don't even see you. They never learn your name. Without recognition, there's no reciprocity; there's not even a 'you' to respond to. And without reciprocity there's no real relationship of respect. (Gecan, 2002: 36)

The campaign has now become a national campaign spreading to many other cities and areas across the country drawing in hundreds of other local institutions. In addition, the links and working relationships formed with unions have been highly significant albeit not without its difficulties (see article by Jane Holgate, 2013 entitled 'Faith in unions: From safe spaces to organised labour?').

Second, the epistemological basis of community organising and the vision of 
the good society promoted by Citizens UK is understood as something that emerges out of struggle and the tension between 'the world as it is' and the 'world as it should be'. According to Chambers:

$\ldots$ it is the fate of human beings to exist in-between the world as it is and the world as it should be. Reflective people of conscience are constantly and painfully aware of the gap between our so-called values and the facts of life in the everyday world within which we operate ... The tension between the two worlds is the root of radical action for justice and democracy. (Chambers, 2003: 29)

Third, and linked to the last point is the importance in community organising of an understanding of the public sphere as being essentially contested between market, state and civil society actors (Bunyan, 2013). Within the academic literature a distinction is often made between community development and community organising, the former being identified as a more consensus-based approach and the latter more conflict-based. The distinction represents, in my view, a false dichotomy in that the repertoire of political action available to an organisation depends largely upon the power it is able to generate, particularly in terms of numbers of people and their willingness to act for change. The aim is not be conflictual for the sake of conflict or as a result of a predisposed ideology. Rather in seeking recognition for the issue at hand, with the aim of moving to some form of consensus, it is more advantageous for civil society organisations to have a potentially wide repertoire of political action and a range of different available tactics, both consensus- and conflict-based. The living wage campaign in the way it has evolved provides a good example of such a strategy and approach.

Fourth, has been the way the campaign has managed to break down a structural problem, poverty, into a winnable issue, the fight for a living wage. In his analysis of broad based community organising and the approach of Citizens UK and its main affiliate London Citizens in building political agency, Bretherton highlights the distinction made between 'problems' and 'issues'. He says:

A problem is an amorphous, multifaceted, and generalised structural condition such as crime or poverty or a lack of affordable housing. In contrast to a problem, an 'issue' is a specific and potentially 'winnable' course of action or proposal targeted at specific people and institutions ... A central insight of broad based community organising as a form of political action is that motivating and mobilising people to act together for change entails identifying the possibilities for agency through breaking structural problems down into winnable issues. (Bretherton, 2015: 132)

Finally, in terms of social justice understood in redistributive terms we can say that the living wage campaign represents a significant civil society-led intervention and means of pre-distribution. As discussed earlier, within the context of neo-liberalism, exacerbated in recent years by austerity, arguments for the redistribution of resources to the poor through increased state intervention have become increasingly difficult to make. Against this challenging context the living wage campaign has shown that civil society organisations can organise effectively and generate sufficient agency to influence both the market and the state in the way that resources are distributed.

\section{Civil society and radical democratic politics}

The broader question going forward in thinking about the nature of social justice and the role of civil society in addressing 
issues of poverty and inequality is whether a progressive politics can be forged in which civil society plays an increasingly central role. A number of criticisms have been levelled at community organising, particularly from the left, for example that it remains primarily focused on the local and thus is limited in its capacity and potential to impact at a structural and broader national level. Also, that the non-partisan stance of community organising to electoral party politics similarly limits its potential broader impact. Against these claims and within the context of the UK it can be said that community organising whilst retaining a focus on the local has moved onto a broader stage through both developing effective city-wide organisations, most notably London Citizens, and building effective campaigns such as the living wage campaign and most recently the campaign to resettle Syrian refugees. It can be also argued that community organising has had a significant impact on policy and party politics. As mentioned earlier, whether one agrees with them or not, the 'Big Society' community organising programme and the national living wage were ideas co-opted from community organising by the Conservative party. Similarly, the development of the Blue Labour project, as narrated in Rowenna Davis's (2011) book 'Tangled up in Blue: Blue Labour and the Struggle for Labour's Soul' highlighted the central role of community organising and its impact on the main protagonist and architect of Blue Labour, the peer Maurice Glasman.

That said, it is my contention that if community organising is to continue to grow and have greater influence and impact at a broader level, there is work to done in developing a stronger theoretical basis for the work, not least in better understanding the condition of neo-liberal hegemony and how this is best countered and challenged on a broader political front. Thinkers on the Left are struggling with this problematic and there is much, I would contend, that community organising can draw upon in developing a broader strategic view and a stronger theoretical basis.

For example, in their analysis of socialist strategy and call for a new form of radical and democratic politics, Laclau and Mouffe point to the contingent nature of what they term, 'the social', i.e. society, and the possibilities for a new hegemonic strategy which focuses on civil society as much as the state. They say,

It is not in the abandonment of the democratic terrain but, on the contrary, in the extension of the field of democratic struggles to the whole of civil society and the state that the possibility resides for a hegemonic strategy of the Left. It is nevertheless important to understand the radical extent of the changes which are necessary in the political imaginary of the Left if it wishes to succeed in founding a political practice fully located in the field of the democratic revolution and conscious of the hegemonic articulations which the present conjuncture requires. (2001: 176)

The authors highlight a number of obstacles which in their view seriously limits the Left's capacity for action and political analysis. First, statism - 'the idea that the expansion of the role of the state is the panacea for all problems' (p. 177); second, classism - 'the idea that the working class represents the privileged agent in which the fundamental impulse of social change resides' (p. 177); thirdly, revolution, understood in the Jacobin mould, that is, the idea that power could be seized in a decisive moment or event 'from which society could be "rationally" reorganised' (p. 177). In questioning these tenets of leftist thinking, Laclau and Mouffe's central argument is that social change and radical democracy need to be conceived in terms of a plurality of struggles: 'The multiplication of political spaces and the preventing of power in one 
point are then the preconditions of every truly democratic transformation of society' (p. 178).

In advocating a move away from essentialist thinking which conceives of social change in a particular way, i.e. in terms of state, class and revolution, Laclau and Mouffe challenge the Left to think in more expansive terms about how to combat what they term the 'anti-democratic offensive' embodied in recent times by neo-liberal hegemony. To this end, they contend, it is both the state and civil society which should be conceived as the terrain upon which human agency and the multiplication of political spaces and democratic struggles are to be developed.

Marrying analysis of radical democratic politics from the left with the practice and theory of community organising is a potentially complex task beyond the scope of this paper but it is my contention that the living wage campaign and the approach of community organising more generally, as seen in the practice of Citizens UK, provides an important example of a form of radical democratic civil society-led politics which sits within the conceptual analysis and framework advocated by Laclau and Mouffe.

\section{Conclusion}

The so-called 'national living wage' for over 25s implemented in April 2016 represents a significant intervention by the Conservative government but like its predecessor the national minimum wage introduced by New Labour in 1998 it is set too low to effectively address poverty and inequality in the UK.

In a neo-liberal age in which the market fails to pay sufficient wages to ensure a decent standard of living and the state fails to legislate to compel the market to do so, then it is right that civil society organisations contest the public sphere to promote an alternative vision of the world as it should be, free from poverty and inequality. Based upon a normative understanding of social and political change as arising from struggle and tension as much as consensus, the living wage campaign and the practice of community organising more generally points to the possibilities of a new kind of politics in which civil society builds sufficient power to more effectively challenge the practices of the market and state which diminishes human dignity. To this end, it represents one of the most successful civil society-led initiatives to reduce poverty and inequality in the UK in recent decades.

\section{Declaration of conflicting interests}

The author(s) declared no potential conflicts of interest with respect to the research, authorship, and/or publication of this article.

\section{Funding}

The author(s) disclosed receipt of the following financial support for the research, authorship, and/or publication of this article: the Webb Memorial Trust.

\section{References}

Bretherton L (2015) Resurrecting Democracy: Faith Citizenship and the Politics of a Common Life. Cambridge: Cambridge University Press.

Bunyan P (2013) Re-conceptualising civil society: Towards a radical understanding. VOLUNTAS: International Journal of Voluntary and Nonprofit Organizations 25(2): 538-552.

Cambridge Policy Consultants (2014) Living Wage Special Initiative Evaluation. Cambridge: Cambridge Publishing Management Ltd.

Chambers E (2003) Roots for Radicals. New York, NY: The Continuum International Publishing Group Ltd.

D'Arcy C and Kelly G (2015) Analysing the National Living Wage: Impact and 
Implications for Britain's Low Pay Challenge. London: The Resolution Foundation.

Davis R (2011) Tangled up in Blue: Blue Labour and the Struggle for Labour's Soul. London: Short Books Ltd.

DeFilippis J, Fisher R and Shragge E (2010) Contesting Community: The Limits and Potential of Local Organizing. New York, NY: Rutgers University Press.

Edwards M (2010) Civil Society, 2nd ed. Cambridge, MA: Polity Press.

Fraser D (2003) The Evolution of the British Welfare State. Basingstoke: Palgrave Macmillan.

Fraser N (1997) Justice Interruptus: Critical Reflections on the "Postsocialist" Condition. London: Routledge.

Fraser N and Honneth A (2004) Redistribution or Recognition: A Political-Philosophical Exchange. London: Verso Books.

Gecan M (2002) Going Public. Boston, MA: Beacon Press.

Harvey D (2005) A Brief History of Neoliberalism. Oxford: Oxford University Press.

Holgate J (2013) Faith in unions: From safe spaces to organised labour? Capital \& Class 37(2): 239-262.
Kelly G (2015) Raising low pay is welcome. But we should still fear the forces hurting family incomes. The Guardian 12th July 2015.

Laclau E and Mouffe C (2001) Hegemony and Socialist Strategy: Towards a Radical Democratic Politics, 2nd ed. London: Verso.

McCarron A and Purcell L (2013) The Blame Game must Stop: Challenging the Stigmatisation of People Experiencing Poverty. Manchester: Church Action on Poverty.

MacKinnon D (2000) Managerialism, governmentality and the state: A neo-Foucauldian approach to local economic governance. Political Geography 19(3): 293-314.

Ryan JA (1906) A Living Wage: Its Ethical and Economic Aspects. London: Macmillan.

Wills J and Linneker B (2014) In-work poverty and the living wage in the United Kingdom: A geographical perspective. Transactions of the Institute of British Geographers 39: 182-194.

Young IM (1990) Justice and the Politics of Difference. Chichester: Princeton University Press. 